Jelena Erić Nielsen ${ }^{1}$

Vesna Stojanović-Aleksić ${ }^{2}$

Dejana Zlatanović3

University of Kragujevac

Faculty of Economics
SCIENTIFIC REVIEW ARTICLE doi:10.5937/ekonomika1902087E

Received: February, 20, 2019

Accepted: May, 09, 2019

\title{
THE CHALLENGES OF MANAGING THE ENTREPPRENEURIAL ORGANIZATION
}

\begin{abstract}
The research goal is to explore how to transform organization, with conservative management, organizational structure and culture, into an entrepreneurial one. We hypothesize that organic organizational structure, entrepreneurial culture and appropriate management decisions are crucial for enhancing entrepreneurial initiatives. A relevant theoretical overview is provided, incorporating in depth analysis of investigated issues. This paper contributes by revealing the relevance of adjusting organizational design and management style, to make it more innovation friendly and compatible with needs of individual entrepreneurs in organization. Based on these considerations we note our conclusions, and suggest that academicians provide a more fine-grained depiction of firm-level entrepreneurship, as an avenue for future research.
\end{abstract}

Key words: entrepreneurship, innovation, management, organization, structure, culture

JEL classification: L2, M13, O30

\section{ИЗАЗОВИ УПРАВЉАЊА ПРЕДУЗЕТНИЧКОМ ОРГАНИЗАЦИЈОМ}

\begin{abstract}
Апстракт
Основни цчиљ истраживања је испитати како трансформисати организаичју, са традиционалним менаиментом, организационом структуром и конзервативном културом, у предузетничку. Полазне претпоставке су да је органска организациона структура, предузетничка култура и одговарајуће одлуке менацмента кључни за подстицање предузетничке иницијативе. У раду је презентирано релевантно теоријско истраживање, укључујући критички осврт на анализиране теме. Рад доприноси литератури указивањем на значај прилагођавања организационог дизајна и стила менацмента, како би се креирао подстицајан амбијент за иновачије, усклађен са потребама појединаца са предузетницким потениијалом. На бази спроведених разматрања изведени су одговарајући
\end{abstract}

\footnotetext{
1 jelena_eric@kg.ac.rs

${ }^{2}$ vesnasa@kg.ac.rs

${ }^{3}$ dejanaz@kg.ac.rs
} 
закључщи, и дате препоруке у погледу правияа и важности опсежнијих истраживања организачионог предузетништва у будућности.

Кључне речи: предузетништво, иновација, менаумент, организација, структура, култура

\section{Introduction}

The beginning of new milenium is designated by rapid reafirmation of organizational entrepreneurship, perceived as fundamental precondition for gaining long-term competitive advantage. In hectic and turbulent global economy, organizations are facing neverending change, resulting in the increasing need for proactive behavior and continual innovation.

Inside the organization there is a constant tension between the need for stability and the need for innovation. Stability is essential for daily operations, maintaining efficiency and effectiveness, and securing current competitive position in a short run. However, in a long run, stability and securing current competitive position are two mutually colliding goals. In order to protect a competitive position in the future, it is necessary to embrace risk taking innovations, disturbing current business routines. Organization revitalization and rejuvenation is a necessity, but real challenge and the main research topic is how to transform the traditional into an entrepreneurial organization. It involves creation of preconditions for encouraging employees entrepreneurial activities by adapting the structure, culture and management style, to enable the company to efficiently respond to better and more innovative products. In accordance with the defined research subject, two main objectives of this paper and appropriate scientific hypothesis have been developed.

Paramount concern for organization is how to create nurturing environment, where new ideas can be successfully developed, tested and implemented. It implies that not all organizational structures, nor cultures, are equally capable of supporting employees' innovative behavior. which is the subject of consideration in further analysis. In line with the research subject, the first hypothesis in the paper advocates in favor of organic organizational structure, as the most suitable for encouraging organizational entrepreneurship, and entrepreneurial culture, with open communication channels, decentralized authority, clear vision and strategic direction.

Organization with tendency to become entrepreneurial must be as eficient as possible in innovation efforts, with very limited and scarce resources. Therefore, the objective of this paper is to provide more in depth insight in dilemas and challenges managers are facing on daily basis, trying to maintain current level of business activities and performance, but in a same time how to proceed in attempt to develop and enhance core competence and ensure future position. Special considerations are focused on appropriate leadership style, providing incentives for employees, managers behaviours and values. The second hypothesis is that management decisions are fundamentaly determining course of action in organzation relating to entrepreneurial initiatives.

The paper is structured in following way: after the introduction, the first section elaborates entrepreneurial organizational structure and culture. The second section 
is devoted to explanation of key aspects and challenges of managing entrepreneurial organization. In third section, more specific elaboration about role and responsibilities of top management is presented, with special highlights on different responsibilities depending on management level in organizational hierarchy. Finally, relevant conclusions are derived and provided recommendations for further research avenues.

\section{Entrepreneurial organizational structure and culture}

Different organizational structures are not equally capable to support the employees' innovative behavior. Problems companies are facing with competitiveness stem from their capacity for innovation, limited R\&D investments, inadequate resource allocation, and lack of fruitful collaboration with research institutions (Jovanović, 2018). Numerous researchers have been analyzing optimal solutions and preconditions for encouraging and enhancing entrepreneurial initiative, especially in the context of designing and developing an adequate organizational structure (Burgelman, 1984; Sathe, 1989; Guth \& Ginsberg, 1990; Zahra, 1991; Hornsby, Naffziger, Kuratko \& Montagno, 1993; Hisrich, Peters \& Shepherd, 2008, pp. 75-77). The structure must have capacity to respond to environmental turbulence (competition, technology, market), handle internal priorities (efficiency, effectiveness, coordination, control, etc.), but also to provide space for potential entrepreneurs to step forward and start developing innovative ideas. Designing an adequate organizational structure implies taking a number of decisions reffering to specialization, departmentalization, coordination, and control (Galbraith, 1995).

It is possible to distinguish several types of organizational structures (Miler, 1986, 1996):

- simple structure - low specialization and formalization, coordination is carried out by direct supervision, centralized authority; innovation intensity and frequency depends on managers' knowledge and awareness;

- mechanical bureaucracy - organizational structure based on firm hierarchy and bureaucracy, coordination through standardization, high centralization and formalization, technology automated and integrated into business activities, fully developed and internally oriented information system;

- organic structure - flexible, with loose hierarchy, limited bureaucracy and procedures, intensive cross-functional cooperation, designing and developing complex products with a short life cycle, reactive externally oriented information system, emphasis on interpersonal relations, communication, authority decentralized and based on expertise (Miller, 1983);

- divisional structure - divisions as profit centers created on the product/market base, with more or less organic structure, entrepreneurial intensity varies, permanent tendency towards higher formalization, getting more bureaucratized in time, acting autonomously, authority delegated to division managers, control facilitated through sophisticated management information system. The divisions are mainly focused on incremental innovation, so entrepreneurial efforts are at a low or medium level (Besanko, Dranove, Shanley, \& Schaefer, 2004, pp. 543-545).

The requirements of an entrepreneurial organization do not match a traditional organizational structure, which implies that the organization cannot be both organic 
and mechanistic, at the same time (Burns \& Stalker, 1961). Traditional enterprises cannot withstand the pressure of their competitors without innovations (Kostić, 2018). Standardized activities such as payroll, accounting, taxation, procurement tend to be highly bureaucratic, while new products development, marketing and strategic planning require a more flexible organic structure (Grant, 2009, pp. 182-183).

The organic structures favor the development of innovativeness and enhance the employees' entrepreneurial behavior. Entrepreneurship will develop under conditions of open communication, decentralized authority, clear vision and the strategic direction defined at the top of the organization. Interfunctional cooperation and interaction are priorities, as well as the realization of low formalization. Decisions often take place in the short term, and decisions are partly rational, and partly intuitive. Changes in production and modern communications provide management with new opportunities in designing an organization that needs to be distinguished by the "structure, decentralized decision making, tolerance to uncertainty, porous internal and external borders, employee empowerment, capacity of reconstruction, autonomous organizational units and integrated coordination mechanisms" (Daft \& Levin, 1993).

The organic structure is suitable for enhancing innovativeness, positively influencing the employees' entrepreneurial intentions. Entrepreneurship will thrive in organization with open communication channels, decentralized authority, clear vision and strategic direction. Interfunctional cooperation and interaction are priorities, as well as maintaining relatively low formalization. Decisions often take place in the short term, and decisions are partly rational, and partly intuitive. Constant change in production and modern communications provide management with new tools in designing an entrepreneurial organization, with flat structure, decentralized decision making, uncertainty tolerance, flexible boundaries, empowered employees, renewal capacity, autonomous organizational units and integrated coordination mechanisms" (Daft \& Levin, 1993).

Organizational culture is a system of common values, attitudes and ways of thinking shared by employees in the organization and transferred to new employees, as the only correct one (Bratton \& Gold, 2003, p. 485). It defines a set of beliefs and assumptions about how employees should behave, what is the purpose of the organization is and what is preferred competitive position.

There are essentially invisible and formally visible aspects of organizational culture (Schein, 1984). The essence refers to a common system of values, beliefs and norms, while the visible aspects represent the ways how culture is expressed, promoted and transferred, i.e. language, myths, rituals and ceremonies. Culture has several important characteristics: collective spirit, implying that most employees in the organization share the content. Culture is emotional, enables employees to identify themselves at an affective level. It is traditional, reflecting the history of interpersonal relations, but dynamic at the same time. Organizational culture is also highly symbolic, with rituals, symbols, attitudes, etc. expressing the pride of the employees for joint achievements and belonging to the company. Finally, culture is ambigous, encompassing contradictory elements, leading sometimes to opposite interpretation of the company's basic values. A strong organizational culture emanates a unique, consistent message to employees about preferred behavior, in order to help them deal with everyday challenges, goals and collaboration with stakeholders. 
Traditional, conservative culture corresponds with a mechanistic organizational structure, strong hierarchy, established procedures, routines and embeded control methods. Entrepreneurial culture, on the other side, corresponds to a flat organic structure, authority decentralization and teamwork. Open communication contributes to mutual thrust, creating more space and willingnes to accept of new ideas. Traditional business founded on organizational culture embracing conservative decision-making is nowadays facing dramatic challenges (Hisrich et al., 2008, pp. 69-73). New proposals and projects sometimes take so much time and require dealing with complex procedures that hardly anyone is willing to take responsibility and step forward. Implicit internal message of conservative culture are to stick to the rules, follow the instructions, take no initiative, and mind your own business. A culture that promotes risk aversion, will automaticly and systematically discourage employees from entrepreneurial behavior. Such an environment is unsuitable for development of new ideas and does not provide freedom to act.

A strong, positive and consistent culture is crucial for encouraging entrepreneurial behavior in the organization. In most cases it takes between seven and ten years for management to transform the traditional organizational culture into an entrepreneurial one. The tendency to act in entrepreneurial way represents essential ingredient of culture, more or less embedded in organizational identity. Entrepreneurial companies are lead by a vision, an idea of the organization as it is now and what it's striving to become. The vision goes beyond the scope of current business and goes far into the future. The essence of a vision lies is an ideology, encompassing the basic values, purpose and raison d'être of an organization. Ideology is constant, it is not adjustable to the change of products, markets, or leadership. Entrepreneurial management creates a culture that promotes creativity, innovation and exploration. In entrepreneurial culture, the main focus is on the future, and the ability to develop and transfer knowledge is highly appreciated. The ultimate goal is to empower employees to develop through innovation and the quest for excellence, as well as willingness to take responsibility (Ireland, Kuratko, \& Morris, 2006).

\section{Managing entrepreneurial organization}

Entrepreneurial ventures are initiated by individuals, but in an entrepreneurial organization, all employees have a responsibility for opportunities identification and exploitation. In an organization managed in an entrepreneurial way, there is a strong tendency for accelerated growth. Traditionally managed companies tend to grow in a moderate pace, without compromising daily operations, risking resources or jeopardizing current managerial structure and positions. Most of the companies are somewhere between these two extremes, leaning more or less toward one of them (Hisrich et al., 2008, pp. 45-46).

In organizational development, entrepreneurial management plays a key role, encouraging new value creation through innovation. Management is willing to embrace the latent conflict in the organization, since ongoing activities ensure maintaining competitive position, while entrepreneurial are currently disturbing embedded patterns and bring discomfort, but aiming to secure the market position in the long run. 
Entrepreneurial and traditional management are fundamentally different. From the perspective of traditional management, entrepreneurial enterprises are managed badly and inefficiently. Traditional and entrepreneurial management is different, in terms of strategic orientation, opportunity commitment, allocation resources, management structure, rewarding philosophy, growth orientation, and organizational culture. (Stevenson \& Gumpert, 1985). Traditional management is focused on loss prevention and efficiency in the present, while entrepreneurial is oriented toward value creation, opportunities recognition and identifying prospective activities in the future.

Subtle signals management is transferring to employees have much stronger impact on their behavior, comparing to formal organizational documents. Emotions displayed by managers severely affect employees' behavior, but in a same time they represent significant signal about their preferred activities. Manager's emotional intelligence and self-control is a powerful instrument of motivation. Employees will be more willing to behave in entrepreneurial manner if manager is demonstrating self-confidence and optimism, and vice versa, if constantly confronted with frustration, concern, and confusion (Brundin, Patzelt, \& Shepherd, 2008). Self image, experience, feelings and affects represent the reflection of ongoing cognitive processes, and consequently influence entrepreneurial intentions and behaviour (Erić Nielsen \& Stojanović-Aleksić, (2015).

Entrepreneurial leadership possess the ability to influence others to strategically manage resources in order to encourage quest for opportunities and sources of competitiveness (Covin \& Slevin, 2002; Ireland, Hitt, \& Sirmon, 2003). The entrepreneurial leader must convince the followers that entrepreneurship is integral part of organizational values and the responsibility of each and every employee. It helps in motivating potential entrepreneurs, providing support in innovation development and securing the necessary resources (Hornsby, Naffziger, Kuratko, \& Montagno, 1993).

When top management clearly promotes an entrepreneurial strategic vision, employees will have more courage, orientation and moral justification to behave entrepreneurially (Ireland, Covin, \& Kuratko, 2009). There must be a consensus about dominant logic, implying consent about expectations, signalizing which opportunities are important, which behaviors are appropriate and which results are valuated (Dess, Ireland, Zahra, Floyd, Janney, \& Lane, 2003). Resource exchange is a mechanism enabling leaders to manage and direct the employees' behavior. The key resources being exchanged are money, material goods, services, status, information, and affection (Foa \& Foa, 1974). Understanding the employees' preferences about resources is enabling leader to strengthen entrepreneurial initiatives through demonstration of the appropriate leadership style and adequate incentives, above all compensation system.

The managerial perceptions of the environment and the frequency of providing support for entrepreneurial innovations vary depending on the hierarchical level (Hornsby, Kuratko, Shepherd, \& Bott, 2009). The interdependence between managerial support and frequency of entrepreneurial activities is stronger at higher organizational levels.

Top, middle and operational management have different responsibilities and roles initiating and implementing entrepreneurial activities (Floyd \& Lane, 2000). At the strategic level, managers are putting effort to identify effective ways to create new or redefine existing business. The middle management proposes and develops entrepreneurial ideas aiming to improve the organization's competitive position. 
Operational management is focused on how organization core competence can be used in the process of opportunities exploitation.

\section{The role of top management in building entrepreneurial organization}

Top management needs to allocate enough time and effort to clearly and systematically promote innovation as core organizational value, with far-reaching potential benefits (Goffin \& Mitchell, 2010, cc 325-327). Dess et al. (2003) argue that that the top managers' leadership role is crucial for designing organization capable to support internal entrepreneurship. Entrepreneurial orientation will result in enhanced competitiveness only if accompanied with adequate support from strategic management (Erić, Babić, \& Nikolić, 2016). Top managers must create an entrepreneurial organization where innovative ideas will emerge regardless of managerial supervision and monitoring. Organizational architecture represents overall internal environment, i.e. the organizational context in which the entrepreneurial strategic vision is transformed into specific entrepreneurial processes and behaviors. A flexible organizational structure, innovation capacity, an adequate compensation system, and entrepreneurial organizational culture are increasing the probability of systematic recognition and tendency to exploit opportunities (Ireland et al., 2009). In other words, the strategic management effectiveness in promoting entrepreneurial behavior will fundamentally depend on the internal environment and the available human resources (Morris, Kuratko, \& Covin, 2008, cc. 302-305).

The portfolio of innovative projects must be carefully balanced and integrated into organizational strategy (Goffin \& Mitchell, 2010, cc 188-190, p. 27). The fundamental problem that entrepreneurial management faces is how to effectively manage innovative ideas and projects, often highly risky. Priorities must be set and when possible it is important to specify and quantify the selection criteria. Management support is essential and implies connecting the compensation system to the new venture performance, sending an adequate message to all employees and acting as incentive. (Hisrich, Peters, \& Shepherd, 2008, pp. 75-76). Traditional methods of management by objectives, motivation and control is ineffective, particularly imposing directions for employees to behave in entrepreneurial manner, as this course of action will most likely result in number of superficial and useless ideas, lack of dedication and getting form without substance (Sathe, 1989). Even substantial financial incentives are not recommendable, as they can lead to internal injustice and lack of fair play. Managers often believe that the number of value-adding activities in organization is satisfying, including long-term business relationships and investments, so if new entrants, not bounded with previous contracts and obligations, unexpectedly change competitive environment, organization is facing real problem (Besanko et al., 2004, cc. 598-599). It is necessary to manage the entrepreneurial process in the organization as a whole, not just individual project (Sharma, 1999)

It is difficult to understand the organization core business, without taking into account the personal characteristics and capabilities of the most powerful internal stakeholder, top management. The central idea of the upper echelons theory is that the way managers are taking decisions dominantly depend on their interpretation of the 
strategic context, based on previous experience, values and personal characteristics (Hambrick, 2007). The main precondition for enhancing the innovativeness is presence of autonomous entrepreneurial behavior throughout the organization. It implies that not only employees, but managers too, have high risk propensity, they are creative, dynamic and ready to pursue the entrepreneurial opportunity.

Thus, strategic management is facing a complex entrepreneurial challenge, including taking decisions about following key issues (Morris et al., 2008, pp. 305-307): nourish of entrepreneurial capability, protect disruptive innovations, make opportunities make sense, question the dominant logic, link entrepreneurship and strategy.

Doing business in accordance with these requirements creates the basis for building competitiveness in the future. Top managers provide encouragement and backup for these activities, and on rare occasions, they might even directly communicate with an entrepreneurial team. In order to promote corporate entrepreneurship it is crucial to maintain open communication and trust. That way it is easier for management to decide about resource allocation in favor of the entrepreneurial venture. Entrepreneur is fundamentally interested his idea to be as visible to top management as possible and to adequately communicate with lower level managers. Managers should demonstrate confidence in employees, their knowledge, experience and capability to evaluate, rather than formal analysis, calcualtions or their own convictions. Regardless of the position, management should primarily provide an advice, rather than imposing or dictating solutions. It is possible to predefine the part of the overall budget that organizational units can allocate for entrepreneurial activities, according to their size and scope of activities. In this way, the resource allocation decisions are decentralized, but management is still retaining enough space for maneuvering (Sathe, 1989).

In most organizations, top managers are primarily focused on monitoring the current operations and maximizing performance. In the entrepreneurial organization, they take responsibility for the emerging initiatives and help them to move forward. One of the biggest challenges for strategic management is how to balance market validated and successful ongoing operations with unproven innovations, but potentially crucial for future competitiveness. They must take into account current business, maximizing performance, satisfying preferences and outperforming competitors, because without that, there will be no future for organization. The activities of maintaining and changing the status quo in organization are putting top management in a schizophrenic position, and this ambiguity is reinforced when they assume direct responsibility for both streams of action. While managing current business, new track for the future should be set.

Management at all levels should be able to have the profound understanding of the business, which can be achieved by rotation or expanding the field of expertise. An alternative approach is also possible, to hire an external manager, with appropriate experience and competence related to the product, market, technology, etc. In this way, the organization can get a lot, provided the new manager is embraced by employees, demonstrates credibility, and fits well into political processes (Sathe, 1989).

In spite of the enormous positive effects and the importance of getting support in the implementation of entrepreneurial ideas, in reality, top management it often resistant and unwilling to help. Management efficiency is evaluated based on short term organizational performance, so shareholders need to find a way, via board of directors, to encourage managers to engage in promoting internal entrepreneurship (Zahra, 1996). Managers owners are more prone to encourage entrepreneurial behavior. 
A high proportion of outsiders in the board is positively correlated with corporate entrepreneurship, and this interdependence is getting stronger if outsiders have more shares. Separation of board director and CEO positions also has a positive impact on internal entrepreneurship. The size of the board of directors is linked with entrepreneurial initiative in a non-linear manner: there is a positive correlation up to a certain board size, but consequently it becomes too large, negatively influencing entrepreneurial initiatives (Zahra, Neubaum, \& Huse, 2000).

An additional problem for strategic management is how to make sure that lower managerial levels do not take advantage of the freedom given to them, through possible irresponsible behavior. Tactical managers differ in their structural capacity to put in action top management willingness to support entrepreneurial activities. Middle level managers, closer to the top of the organization will be better positioned to estimate the nature and scope of top management support. Conversely, operational managers are more distant to top management, and sometimes do not have sufficient information about top management position, perceptions and future plans. This implies that, if there is adequate backup from the top, more entrepreneurial ideas will be implemented by middle and senior, than by operational management. Likewise, higher working autonomy, available time, flexible organizational boundaries and an adequate compensation system increase the number of ideas implemented by middle and senior, compared to the operational management (Floyd \& Lane, 2000).

\section{Conclusion}

Restructuring organization is often conducted without paying attention to entrepreneurial activities, disregarding and underestimating necessity for constant innovation, as a tool of maintaining long term competitive advantage. Entrepreneurship must be clearly pointed as one of the explicit priorities in redesigning the organization, with clear and unambiguous support of management structure. Competitive potential of organization can be fully exploited only under appropriate circumstances, in friendly and nurturing internal environment.

Strategic management is focused on creating and developing new or redefining current business, while middle and operational managers are more preoccupied with exploitation of organizational competencies through implementation of innovative ideas. For academics and researchers, who recognize the importance of entrepreneurship, we suggest to focus on methodological rigor, conceptual depth, and applicability. The quest for new sources of competitiveness is raising a series of issues on the theoretical and practical level, and limited knowledge is making the creation of internal environment favorable for entrepreneurial initiative even more challenging. Recommendation for managers and practitioners is to establish incentives and compensation system, to communicate entrepreneurial vision and strategy, to highlight flexibility in strategy implementation and become role model in promoting employees innovative behavior. If managers perceive themselves as innovative, willing to take risk and experiment, the rest of the organization will follow. 


\section{References}

Besanko, D., Dranove, D., Shanley, M., \& Schaefer, S. (2004). Economics of strategy, $3^{\text {rd }}$ ed., New Jersey, John Wiley \& Sons, Inc.

Bratton, J. \& Gold, J. (2003). Human Resource Management: Theory and Practice, Basingstoke, Palgrave Macmillan.

Brundin, E., Patzelt, H., \& Shepherd, D. A. (2008). Managers' emotional displays and employees' willingness to act entrepreneuially. Journal of Business Venturing, 23, 221-243.

Burgelman, R. A. (1984). Designs for corporate entrepreneurship in established firms. California Management Review, 26 (3), 154-166.

Burns, T. \& Stalker, G. M. (1961). The management of innovation, London, UK: Tavistock.

Covin, J. G. \& Slevin, D. P. (2002). The entrepreneurial imperatives of strategic leadership. In M. A. Hitt, R. D. Ireland, S. M. Camp, \& D. L. Sexton (Eds.), Strategic entrepreneurship: Creating a new mindset (pp. 309-327), Oxford, Blackwell Publishers.

D. L. Sexton (Eds.), Strategic entrepreneurship: Creating a new mindset (pp. 309327), Oxford, Blackwell Publishers.

Daft, R. \& Levin, A. (1993). Where are the theories for the new organizational form? Organization Science, 4 (4), 1-6.

Dess, G. G., Ireland, R. D., Zahra, S. A., Floyd, S. W., Janney, J. J., \& Lane, P. J. (2003). Emerging issues in corporate entrepreneurship. Journal of Management, 29 (3), 351-378.

Erić Nielsen, J. \& Stojanović-Aleksić V., (2015). Cognitive Foundation of Corporate Entrepreneurship as a Mean of Sustainable Competitiveness and Growth. Proceedings from Second European Academic Research Conference on Global Business, Economics, Finance and Banking, 3-5.07, Zurich, Switzerland.

Entrepreneurial orientation and strategic management. U V. Stojanović Aleksić, (red.), Contemporary Issues in Economics, Business and Management (str. 6978). Ekonomski fakultet Univerziteta u Kragujevcu.

Floyd, S. W. \& Lane, P. J. (2000). Strategizing throughout the organization: managing role conflict in strategic renewal. Academy of Management Review, 25, 154-177.

Foa, U. G. \& Foa, E. B. (1974). Societal structures of the mind, Springfield, IllThomas.

Galbraith, J. (1995). Designing organizations, San Francisco, CA: Jossey-Bass.

Goffin, K. \& Mitchell, R. (2010). Innovation management, $2^{\text {nd }}$ ed., UK: Palgrave Macmillan.

Grant, M. R. (2009). Contemporary Strategy Analysis, $6^{\text {th }}$ ed., Oxford, UK: Blackwell Publishing.

Guth, W. D. \& Ginsberg, A. (1990). Corporate Entrepreneurship. Strategic Management Journal, Special issue 11, 297 - 308. 
Hambrick, D. C. (2007). Upper echelons theory: An update. Academy of Management Review, 32 (2), 334-343.

Hisrich, R. D., Peters, M. P., \& Shepherd, D. A. (2008). Entrepreneurship, $7^{\text {th }}$ ed., New York, NY: McGraw-Hill.

Hornsby, J. S., Kuratko, D. F., Shepherd, D. A., \& Bott, J. P. (2009). Managers' corporate entrepreneurial actions: Assessing a measurement scale. Journal of Business Venturing, 24 (3), 236-247.

Hornsby, J. S., Naffziger, D. W., Kuratko, D. F., \& Montagno, R. V. (1993). An interactive model of the corporate entrepreneurship process. Entrepreneurship Theory and Practice, 17 (2), 29-37.

Ireland, R. D., Hitt, M. A., \& Sirmon, D. G. (2003). A model of strategic entrepreneurship: The construct and its dimensions. Journal of Management, 29 (6), 963-989.

Ireland, R. D., Kuratko, D. F., \& Morris, M. H. (2006). The Entrepreneurial Health Audit: Is your firm ready for corporate entrepreneurship. Journal of Business Strategy, 27 (1), 10-17.

Ireland, R. D., Covin, J. G., \& Kuratko, D. F. (2009). Conceptualizing corporate entrepreneurship strategy. Entrepreneurship Theory \& Practice, 33 (1), 19-46.

Jovanović, M. (2018). Innovation of Serbia in relation to neighboring countries as a determinant of competitiveness, Ekonomika, 1, 65-78.

Kostić, Z. (2018). Innovations and digital transformation as a competition catalyst. Ekonomika, 1, 13-23.

Miller, D. (1983). The correlates of entrepreneurship in three types of firms. Management Science, 29 (7), 770-791.

Miller, D. (1986). Configurations of strategy and structure: Toward a synthesis. Strategic Management Journal, 7 (3), 233-239.

Miller, D. (1996). A preliminary typology of organizational learning: Synthesizing the literature. Journal of Management, 22 (3), 485-505.

Morris, M. H., Kuratko, D. F., \& Covin, J. G. (2008). Corporate entrepreneurship and innovation, $2^{\text {nd }}$ ed., Mason, Thomson South-Western,.

Sathe, V. (1989). Fostering entrepreneurship in large diversified firm. Organizational Dynamics, 18 (1), 20-32.

Schein, E. H. (1984). Coming to a new awareness of organizational culture. Sloan Management Review, 25 (4), 3-16.

Sharma, A. (1999). Central dilemmas of managing innovation in large firms. California Management Review, 1 (3),146-164.

Stevenson, H. H. \& Gumpert, D. E. (1985). The heart of entrepreneurship. Harvard Business Review, 63 (2), 85-94.

Zahra, S. A. (1991). Predictors and financial outcomes of corporate entrepreneurship: An exploratory study. Journal of Business Venturing, 6, 259-285. 
Zahra, S. A. (1996). Governance, ownership, and corporate entrepreneurship: The moderating impact of industry technological opportunities. Academy of Management Journal, 39 (6), 1713-1735.

Zahra, S. A., Neubaum, D. O., \& Huse, M. (2000). Entrepreneurship in mediumsize companies: Exploring the effects of ownership and governance, Journal of Management, 26 (5), 947-976. 